\title{
Motivation and Attitude: Two Important Non-Intelligence Factors to Arouse Students' Potentialities in Learning English
}

\author{
Yi Liu \\ Faculty of Freshman Education Department, Yangtze University, Jingzhou, China \\ Email: yan.xi.wang@163.com \\ Received 4 June 2014; revised 6 July 2014; accepted 13 July 2014 \\ Copyright @ 2014 by author and Scientific Research Publishing Inc. \\ This work is licensed under the Creative Commons Attribution International License (CC BY). \\ http://creativecommons.org/licenses/by/4.0/

(c) (i) Open Access

\begin{abstract}
This paper discusses how to arouse students' potentialities in learning English by using two important non-intelligence factors: motivation and attitude. With the need to address the diversity of language learners in the contemporary ESL context, the value of non-intelligence factors cannot be underestimated. There are several non-intelligence factors that influence success or failure in English learning, but the two major ones include motivation and attitude. Motivation drives students towards a desired goal, while attitude shapes students' perceptions of the curriculum, peers, as well as the instructor. It is important for language educators to recognize the value of these factors if quality outcomes in terms of English learning are to be delivered.
\end{abstract}

\section{Keywords}

English Learning, Motivation, Attitude

\section{Introduction}

English is increasingly becoming a global language, mainly due to globalization. Just like any other foreign language, learning English is not always an easy task for non-native English speakers (Sheorey, 2006). This explains why several strategies have been suggested to make the learning of English easier. Today, the mastery of English is perceived as a gateway to one's prosperity in the future in an increasingly globalized world. Furthermore, English learners have over the years become younger and younger, with English courses being taught as early as the first grade (Saville-Troike, 2006). Some parents are even compelled to enroll their children in after-school and weekend English lessons in an effort to boost their proficiency in the language.

Nonetheless, language educators are yet to fully recognize the role of non-intelligence factors in the learning 
of English. Some of these factors include attitude, motivation, interest, will, character, and age. In addition to the intelligence factor, these factors play a crucial role in English learning. Motivation, for instance, accounts for 33\% while intelligence takes up 20\% in terms of contributing to English learning (Ochsenfahrt, 2012). In essence, two students may look alike or have similar abilities, but their behavior could be totally different—one may be an active participant in class, while the other may be passive, rarely joining in classroom discussions. This forms the basis of this paper. The paper seeks to examine the role of non-intelligence factors in arousing students' potentialities in learning English, with a special focus on motivation and attitude.

\section{Role of Non-Intelligence Factors in Learning English}

Conventionally, most learning settings have been structured as if all learners possessed similar characteristics (Morgan \& Fonseca, 2004). A phenomenal discovery in the arena of education in the $21^{\text {st }}$ century is that students in the same classroom possess substantially different learning profiles. As a result, the need for recognizing the individual needs of students has become a major issue of consideration in designing teaching and instructional methodologies. The need for differentiated instruction has even been more pronounced in foreign language teaching contexts. Non-intelligence factors, especially motivation and attitude, have been shown to play a crucial role in fulfilling the individual needs of language learners (Pintrich \& Schunk, 2002). These factors raise the awareness of students' individual learning styles by arousing their potentialities in learning a target language and by enabling students to be in charge of their own learning.

\subsection{Motivation}

Motivation is one non-intelligence factor whose influence on English learning is substantial (Kong, 2009). The connection between motivation and language learning has been a major subject of academic discourse since the 1960s. It is widely agreed that motivation constitutes one of the major factors that influence success or failure in language learning and teaching (Mao, 2011). From a psychological perspective, human beings are always motivated, whether or not the motivation causes them to do what other people prefer them to do. Saville-Troike (2006) describes motivation as a force that strengthens and guides behavior towards a goal, the way a force moves an object. If human beings were machines, then motivation would be the very engine that would power and direct their behavior. Besides energizing and guiding us, motivation helps us to choose the most appropriate behavior for attaining our goals (Ochsenfahrt, 2012). Essentially, motivation is an inside state that provokes one's desire for a goal and sustains their efforts in a given direction.

From the perspective of English learning, motivation entails not only a rigorous desire for acquiring English, but also an inside cause that provides the enthusiasm and willingness students need to learn English (Mao, 2011). Motivation creates a fascinating learning environment, thus eliminating boredom—a major deterrent for English learning. In foreign language learning, motivation encompasses four aspects: a goal, effortful conduct, attitude, and a desire to achieve that goal (Pintrich \& Schunk, 2002). Students with robust learning motivation often take a positive attitude towards learning, and most importantly, put in a great deal of effort in mastering English with a clear goal and a strong desire. As a result, they achieve better grades as compared to those without motivation (Dornyei \& Schmidt, 2010). Therefore, the role served by motivation in English learning cannot be overemphasized.

\subsubsection{Classifications of Motivation}

There are several ways in which motivation can be described, but motivation is broadly categorized as intrinsic or extrinsic (Kong, 2009). Intrinsic motivation entails responding to the needs that exist inside the learner, such as the desire to know, curiosity, and feelings of growth or competence. This type of motivation exists when an individual's actions are influenced by an inside desire to complete a task successfully, whether the task comes with some external value or not (Gardner, 2010). In short, students portray the desire to acquire knowledge that is new and fascinating with a motive of satisfying their curiosity, desire to know, and feelings of growth or competence. Importantly, learners with intrinsic motivation study on their personal initiative and often prefer fairly complex tasks (Ochsenfahrt, 2012). This has immense value for second language learning as the inward interest makes students self-starting and maintains the motivational engine going for longer.

Extrinsic motivation on the other hand refers to an outside force that powers the language learning process (Kong, 2009). This force usually takes the form of praise, rewards, recognition, and acknowledgement. Extrinsic 
motivation exists when an individual is influenced by an outcome that is external or not functionally associated with the activity in which he or she is involved. When learning is influenced by the desire to win the teacher's praise or recognition, earn rewards, or to win parents' favor, it can then be concluded that the motivation to acquire knowledge is fundamentally extrinsic (Saville-Troike, 2006). In other words, the student's motive of study lies predominantly outside themselves and the objective of learning entail not only knowledge acquisition, but also the desire for rewards.

As explained by Kong (2009), intrinsic and extrinsic motivations are two inseparable phenomena. They complement each other when it comes to language learning. Intrinsic motivation is the inward force that pushes students forward. Nevertheless, in an actual world setting, not all students are automatically energized to engage in a given task, or to learn a certain topic (Gardner, 2010). At times, an impressive grade, the risk of failing, and praise shift learners from a passive to an active state. Actually, the use of extrinsic motivators such as rewards and praise has been found to enhance intrinsic motivation (Dornyei \& Schmidt, 2010). Though extrinsic motivators play a crucial role in the learning process, overstressing their use has the potential to throttle intrinsic motivation.

Motivation can also be categorized as integrative or instrumental (Mao, 2011). When acquiring a target language, some students have a tendency of liking the fluent speakers of the language (whether native or non-native), admiring the underlying the culture, or even desiring to integrate into the community in which the language is utilized. This is referred to as integrative motivation. With this type of motivation, an individual's desire to acquire a foreign language is provoked by the desire to communicate with members of the target language community (Dornyei, 1994). Integrative motivation exists when the learner desires to learn the culture of the target language. On the contrary, instrumental motivation entails learning a target language for an ulterior motive, whose utilization has no relation to native speakers (Gardner, 2010). Instrumental motivation lays emphasis on the practical elements of language learning without the particular need of communicating with the members of the target language community. While the instrumentally-motivated learner views a target language as a means to some different end, the integrative learner views a foreign language as an end in itself.

\subsubsection{Ways to Arouse Students' Motivation}

Motivating students encompasses not only leading them to English, but also arousing their thirst for knowledge and understanding (Lins, 2006). Unlike other subjects, English learning has individual attributes that require learners to remember, practice, and communicate more. In this regard, English teachers have a duty to boost their students' willingness to participate actively in the language learning process. There are various ways through which students can be motivated: utilization of various fascinating activities, new techniques such as technology, setting expectations and use of rewards, creation of a positive learning environment, and cooperative activities (Kong, 2009).

The use of a variety of fascinating activities can be an effective way of arousing students' potentialities in learning English. Unlike other subjects, English learning involves learning listening, speaking, reading, and writing capabilities by memorizing a great deal of vocabulary grammar and practicing more in and outside class (Nakata, 2006). Given this, blending English learning with recreational activities (such as games, songs, and role-playing) makes the learning process more interesting, which in turn helps in the maintenance of motivation. The use of new techniques also plays an integral role in stimulating extrinsic motivation (Paton, 2009). These techniques include computer assisted language learning (CALL) and the use of technology (the internet, audio, captioned videos, and so on).

In a similar vein, Mao (2011) argues that the utilization of multi-media technologies has turned out to be a widespread phenomenon against the backdrop of tremendous technological advancement. Several scholars have extensively demonstrated the role of technology in the language classroom (e.g. Gu, 2009; Lins, 2006; Nakata, 2006). Computers, projectors, podcasts, mobile devices, and e-readers can all play an instrumental role in the teaching and learning of English as they provide an interactive and motivating environment for learners of all ages.

Today, the language classroom features learners with diverse abilities and academic needs. According to Mao (2011), these differences are mainly brought about by factors such as age, ethnic background, and beliefs. This implies that what works for one student may not work for another student in the same classroom. Language educators have thus been compelled to rethink their teaching methodologies in order to cater for the personal needs of their students. This explains why new techniques such as the use of technology or group discussions are 
increasingly finding their way into the language classroom. According to Gardner (2010), pursuing predesigned curriculum does not always fulfill student needs-customizing teaching strategy is now the way to go.

The other way through which students can be motivated is the use of appropriate rewards and setting expectations (Kong, 2009). At times, our expectations about others make us treat others in a manner that makes them react just as we anticipated them to. Students need to be reenergized by an external force such as teacher praise, rewards, as well as teacher's high expectations. Literature demonstrates that teacher expectations have a significant influence on learner achievement- the higher the expectation, the better the performance (Gardner, 2010; Nakata, 2006; Lins, 2006). Together with positive feedback and positive reinforcement, rewards and expectations stir up students' desire to acquire knowledge.

Creating a positive learning environment entails building an atmosphere that supports both motivation and achievement. In such an environment, students feel secure, ultimately enhancing their sense of understanding as well as their learning motivation (Sheorey, 2006). When learning English, students require plenty of practice, especially in terms of speaking. In this regard, implementing some measures to ensure that they make adequate use of their practice time without experiencing criticism or mockery when they make mistakes creates a safe and comfortable climate for learning. Educators should also create an environment where students can freely express their differing opinions (Paton, 2009). This stretches to viewing mistakes as opportunities for warm remarks and more encouragement. It is also important for teachers to provide tasks that are neither too easy nor too complex for students, since too easy tasks yield boredom and decreased feelings of self-efficacy, while too complex tasks discourage students from trying (Dornyei, 1994).

Cooperative activities can also be an effective way of stimulating student motivation. These activities mainly take the form of group discussions or accomplishing tasks together with peers. Language educators are increasingly using cooperative activities to teach English as opposed to competition, which is fairly effective as well (Gu, 2009). Cooperative activities are effective in that they minimize the fear of failure since reluctant and fearful students are encouraged to participate and share their perspectives. This method is often appropriate for students at an advanced level (Paton, 2009). Cooperative activities enable students to take control of their learning and to be each other's coaches.

\subsection{Attitude}

Another non-intelligence factor that affects English learning is attitude. To successfully acquire a target language, a student must be psychologically prepared. This is where attitude comes in. Attitude, which is closely related to motivation, refers to a pattern of beliefs developed over time in a given socio-cultural context. These beliefs play a critical role in the learning process. There is general consensus that a positive attitude lays the foundation for learning, and vice versa (Mantle-Bromley, 1995; Kuhlemeier, Van Den Bergh, \& Melse; 1997; Bain et al., 2010). Motivated and de-motivated students hold varying perceptions about their teacher, class, and curriculum. It is on the basis of these perceptions that students form attitudes towards English learning.

Mantle-Bromley (1995) strongly believes that students' attitudes should constitute an integral element of second language learning pedagogy. First, attitude yields a substantial influence on simple behaviors such as speaking in a foreign language or even selecting and reading books. Second, there exists a strong connection between attitude towards foreign language learning and foreign language achievement. In fact, the affective element (interest, values, and beliefs) plays a greater role in language learning than the cognitive one (Sheorey, 2006). Given this, realizing students' attitude towards a target language can be of great help to both the teacher and student.

Like every other aspect of cognition development in human beings, attitude is molded early in childhood by factors such as parents, peers, and interactions with different people. Each of these stimuli can result in a positive or negative attitude (Bain et al., 2010). It is therefore important for language educators to recognize the fact that language learning is considerably characterized by the interaction of personalities, and that students are humans as well, with likes and dislikes. As stated earlier, learning takes place more effectively when the learner's attitude towards learning and the target language is positive. Kuhlemeier, Van Den Bergh, \& Melse (1997) add that attitude may not be visible during school life, but educators have a responsibility to assist students develop a positive attitude towards a foreign language.

Foreign language students want teachers who can encourage them to speak more of English in and outside class as well as teachers who can rectify their mistakes without attacking their ego. This explains why throughout history the role of the teacher has shifted from a being a stringent disciplinarian to a facilitator (Bain et al., 
2010). Being a facilitator entails accepting mistakes as integral elements of the language learning process. When a teacher is more of a facilitator than a strict instructor, students develop a positive attitude, which consequently arouses their potentialities in English learning.

\section{Conclusion}

Historically, curricula and teaching strategies have been designed as if all learners possess similar characteristics. It has however been discovered that the contemporary classroom features students with diverse needs and abilities. It is against this backdrop that the value of non-intelligence factors in learning has been recognized. Non-intelligence factors, especially motivation and attitude, serve a crucial role in the context of English learning. Motivation is the force, whether internal or external, that drives an individual to achieve a certain goal. There is a great deal of literature demonstrating that motivation, particularly the use of assorted fascinating activities, emerging techniques, setting expectations and use of rewards, creation of a positive learning environment, and cooperative activities, plays an instrumental role in foreign language learning. Attitude, which is an outcome of chronologically cultivated values and beliefs, is also a critical ingredient of success or failure in the language learning classroom. The student's attitude towards English learning and the language itself determines his or her perceptions about the curriculum, his or her peers, as well as the teacher. Simply put, a positive attitude implies better foreign language performance, and vice versa. In sum, non-intelligence factors play a crucial role in arousing students' potentialities in learning English.

\section{References}

Bain, S. et al. (2010). Learning Aptitudes, Attitudes, Attributions, and Achievement of Postsecondary Students Identified as Gifted. Journal of Advanced Academia, 22, 130-156. http://dx.doi.org/10.1177/1932202X1002200106

Dornyei, Z. (1994). Motivation and Motivating in the Foreign Language Classroom. The Modern Language Journal, 78, 273-284. http://dx.doi.org/10.1111/j.1540-4781.1994.tb02042.x

Dornyei, Z., \& Schmidt, R. (2001). Motivation and Second Language Acquisition. University of Hawaii, Manoa: Second Language Teaching \& Curriculum Center.

Gardner, R. (2010). Motivation and Second Language Acquisition: The Socio-Educational Model. New York: Peter Lang Publishing.

Gu, M. (2009). The Discursive Construction of Second Language Learners' Motivation: A Multi-Level Perspective. New York: Peter Lang Publishing.

Kong, Y. (2009). A Brief Discussion on Motivation and Ways to Motivate Students in English Language Learning. International Education Studies, 2, 145-149. http://dx.doi.org/10.5539/ies.v2n2p145

Kuhlemeier, H., Van Den Bergh, H., \& Melse, L. (1997). Attitudes and Achievements in the First Year of German Language Instruction in Dutch Secondary Education. Modern Language Journal, 80, 494-508.

http://dx.doi.org/10.1111/j.1540-4781.1996.tb05471.x

Lins, T. (2006). Motivation and Second Language Learning. Norderstedt: GRIN Verlag.

Mantle-Bromley, C. (1995). Positive Attitudes and Realistic Beliefs: Links to Proficiency. The Modern Language Journal, 79, 372-386. http://dx.doi.org/10.1111/j.1540-4781.1995.tb01114.x

Mao, Z. (2011). A Study on L2 Motivation and Applications in Reading Class in Senior High School. Theory and Practice in Language Studies, 1, 1731-1739.

Morgan, J., \& Fonseca, M. (2004). Multiple Intelligence Theory and Foreign Language Learning: A Brain-based Perspective. International Journal of English Studies, 4, 119-136.

Nakata, Y. (2006). Motivation and Experience in Foreign Language Learning. New York: Peter Lang Publishing.

Ochsenfahrt, K. (2012). Motivation as a Factor in Second Language Acquisition. Norderstedt: GRIN Verlag.

Paton, A. (2009). Teaching English to Speakers of Other Languages: A Teacher Education Handbook. New York: McGrawHill.

Pintrich, P. R., \& Schunk, D. H. (2002). Motivation in Education. Englewood Cliffs, NJ: Prentice Hall.

Saville-Troike, M. (2006). Introducing Second Language Acquisition. Cambridge: Cambridge University Press.

Sheorey, R. (2006). Learning and Teaching English in India. Delhi: Sage Publications. 
Scientific Research Publishing (SCIRP) is one of the largest Open Access journal publishers. It is currently publishing more than 200 open access, online, peer-reviewed journals covering a wide range of academic disciplines. SCIRP serves the worldwide academic communities and contributes to the progress and application of science with its publication.

Other selected journals from SCIRP are listed as below. Submit your manuscript to us via either submit@scirp.org or Online Submission Portal.
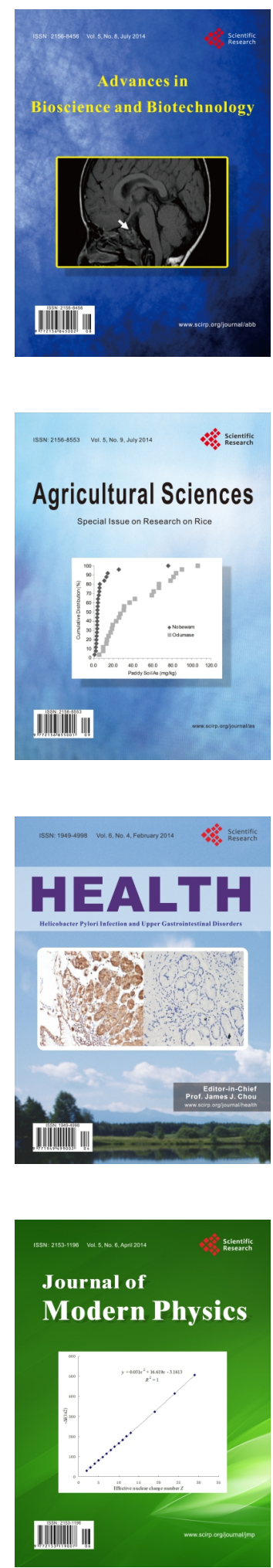
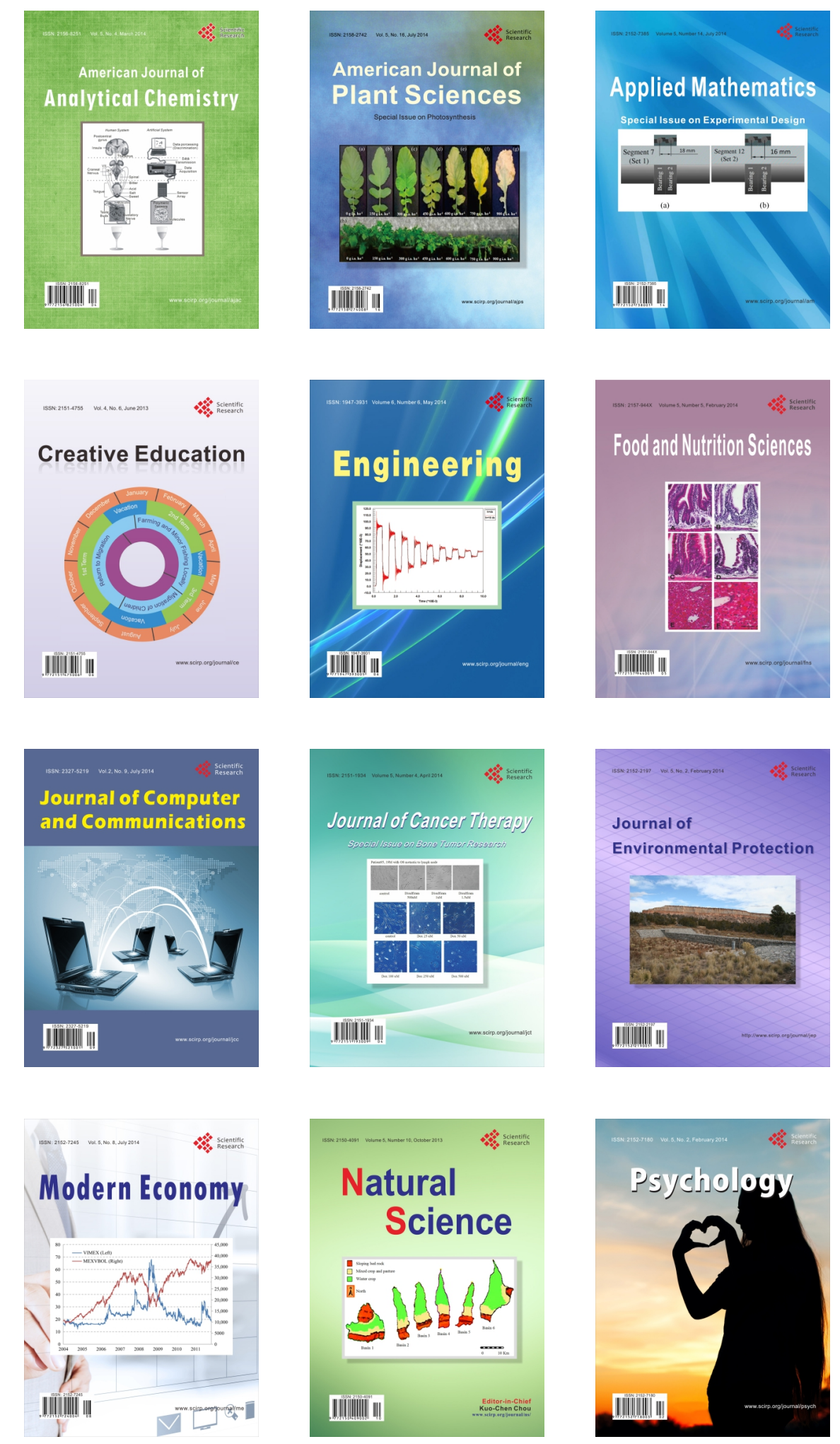